九州大学学術情報リポジトリ

Kyushu University Institutional Repository

\title{
Characteristics of Photosynthesis and Matter Partitioning in Leading Hybrid Rices, Oryza sativa L., Bred in China
}

Kobayashi, Masatoshi

Laboratory of Practical Botany, Faculty of Agriculture, Kyushu University

Kubota, Fumitake

Laboratory of Practical Botany, Faculty of Agriculture, Kyushu University

Hirao, Kenji

Laboratory of Practical Botany, Faculty of Agriculture, Kyushu University

Agata, Waichi

Laboratory of Practical Botany, Faculty of Agriculture, Kyushu University

https://doi.org/10.5109/24079

出版情報：九州大学大学院農学研究院紀要. 39 (3/4)，pp. 175-182，1995-03. Kyushu University バージョン：

権利関係 : 


\title{
Characteristics of Photosynthesis and Matter Partitioning in Leading Hybrid Rices, Oryza sativa L., Bred in China
}

\author{
M asatoshi K obayashi, F umitake K ubota, K enji H irao \\ and $W$ aichi Agata
}

\author{
Laboratory of Practical Botany, Faculty of Agriculture, \\ Kyushu University, Fukuoka 812-81, Japan \\ (Received N ovember 24, 1994)
}

\begin{abstract}
The growth, photosynthesis and yield-determinants of hybrid rices were characterized here in comparison with a pure line cultivar. As experimental materials, leading three hybrids, Shanyou-6, Shanyou-63 and Guangyou-6063, of China and a leading cultivar (pure line), Nipponbare, of Japan were used and grown outdoors in pots. The hybrids showed a vigorous growth and their grain yields (119.6 to $129.7 \mathrm{~g} / \mathrm{plant})$ were 40 to $50 \%$ higher than that $(85.7 \mathrm{~g} /$ plant $)$ of Nipponbare. A large leaf production and higher leaf photosynthetic rate were observed during the early half of the growth season in the three hybrids, both of which were main determinants to the substance accumulation in a plant. The culm+leaf weight of the hybrids increased to the maximum, then rapidly reduced during the maturing stage due to the substance translocation from culms or leaves to panicles. Vigorous development of root system was also a feature of these hybrids : the root weight of the hybrids being several times heavier than that of Nipponbare. The root weight reached the maximum just before or after heading, then decreased rapidly with maturing. It may be suggested that the roots of the hybrids function as a sink organ for substance accumulation before grain filling, and then it changes to a source organ exporting the accumulated substance to panicles during maturing stage.
\end{abstract}

\section{INTRODUCTION}

Breeding of high-yield hybrid rice cultivars, Oryza sativa L., has been carried out in a large scale, recently, and the hybrid rices grown area in China already exceeded 15 million ha by 1990 . The successful use of heterosis in rice production greatly depends on establishment of the breeding system based on male sterile lines, and this is an epoch making technical innovation in the rice breeding history in which all the cultivars used to be improved through the pure line selection before the advent of hybrid rice.

The success of breeding hybrids with exceedingly high productivity gave a strong interest to the researchers, and until now a lot of experiments have been made to understand the high-yield mechanism of hybrids from the physiological and ecological aspects. The following findings are main characteristics for the growth of hybrid rices : a vigorous leaf production at the early growth stage, a large number of spikelets per panicle and unit ground area, an increase in carbohydrate accumulation in culms at the pre-heading stage and a large distribution ratio of dry matter to roots (Song et al., 1990 ; Ichii and Nakamura, 1990 ; Hirao et al., 1993 ; Kubota et al., 1993). Also Hirao et al. (1995) demonstrated that photosynthetic rate per unit weight of soluble protein or RuBPCarboxylase/Oxygenase was higher in the hybrid leaves. 
In addition to these, we have detected a clear difference in matter partitioning pattern in a plant between hybrids and pure line cultivars. From the viewpoint of the matter accumulation and re-translocation in a plant, we explain here the high yield potential of leading hybrid rices of China.

\section{MATERIALS AMD METHODS}

Three hybrid rices, Shanyou-6, Shanyou-63 and Guangyou-6063, were used as experimental materials, all of which were bred in China and widely grown today as high yield cultivars. Of these hybrids, Shanyou- 6 and Shanyou- 63 are Indica type and Guangyou-6063 is Indica- Japonica type. Nipponbare, a leading cultivar (a pure line of Japonica type) grown in Japan, was used as a control to be compared to the hybrids. The seeds of these four cultivars were sown in a nursery box on June 5, 1991, and were grown there for two weeks after germination. Young shoots were transplanted in 8.0 litter pots (one plant/pot) filled with sandy soil. As basal dressing of fertilizer, a compound chemical $\left(\mathrm{N}: \mathrm{P}_{2} \mathrm{O}_{5}: \mathrm{K}_{2} \mathrm{O}=16: 16: 16\right)$ was applied $10 \mathrm{~g}$ per pot, and additional applications of this chemical $(5 \mathrm{~g} /$ pot) were made twice, July 25 and August 9. Those pots were placed in a water pool and sufficiently spaced to each other to prevent the plants from mutual shading.

After transplanting, growth parameters were periodically investigated until the harvest time. Also two plants for each cultivar were sampled eight times at about 10 -day intervals during the period from a month after the transplanting to the harvest. The sampled plants were divided into three to four parts, leaf, culm, root and head, and they were dried at $80^{\circ} \mathrm{C}$ for three to five days and weighed. Leaf area of a plant was measured with an automatic area meter (AMM-8, Hayashidenko, Japan) before drying. Three plants were sampled to determine yield and its components on October 7 to 9. Rates of leaf photosynthesis were measured at different growth stages under sun light condition using a portable photosynthesis/evaporation measurement system (SPB-H3, ADC, UK). When the sun radiation was insufficient to photosynthesis, a halogen lamp (250 watts) was used as a complementary light source. The middle position $\left(6 \mathrm{~cm}^{2}\right.$ of leaf area) of a young fully expanded leaf (photosynthetically most active leaf) was used for measurement.

\section{RESULTS AND DISCUSSION}

\section{Climatic condition, yield and yield components of the four cultivars}

Zhejiang Province, where hybrid rices are widely grown today, is the main rice -producing district of China. Its geographical location is from $118^{\circ} 01^{\prime}$ to $120^{\circ} 10^{\prime} \mathrm{EL}$ and from $27^{\circ} 06^{\prime}$ to $31^{\circ} 11^{\prime} \mathrm{NL}$. The annual average of air temperature is 15.3 to $18.1^{\circ} \mathrm{C}$ and the precipitation is 1,100 to $1,900 \mathrm{~mm} /$ year. While Fukuoka City, the site where our experiment was conducted, is a southern west point $\left(33^{\circ} 35^{\prime} \mathrm{NL}\right.$ and $130^{\circ} 23^{\prime} \mathrm{EL}$ ) of Japan, having $16.2^{\circ} \mathrm{C}$ of annual average air temperature and $1,600 \mathrm{~mm} /$ year of precipitation, both of which are included in the range of those of Zhejiang Province of China. The summer season in the experimental year (1991) at Fukuoka was a little cooler than 
Table 1. Yield and yield-determining factors of the four cultivars.

\begin{tabular}{|c|c|c|c|c|}
\hline Cultivar & $\begin{array}{l}\text { No. of tillers } \\
\text { per plant }(\mathrm{A})^{*}\end{array}$ & \multicolumn{2}{|c|}{$\begin{array}{l}\text { No. of panicles } \\
\text { per plant }(B)^{*}\end{array}$} & $\begin{array}{l}\text { No. of spikelets } \\
\text { per panicle }\end{array}$ \\
\hline Shanyou-6 & 50 & & & 1285 \\
\hline Shanyou-63 & 42 & & & 140.2 \\
\hline Guangyou-6063 & 52 & & & 118.7 \\
\hline Nipponbare & 57 & & & 77.1 \\
\hline $\begin{array}{l}\text { \% of ripened } \\
\text { grains }\end{array}$ & $\begin{array}{l}\text { 1,000-grain } \\
\text { weight }(\mathrm{g})\end{array}$ & $\begin{array}{l}\text { Grain yield } \\
\text { per plant }(\mathrm{g})\end{array}$ & $\begin{array}{l}\text { Plant weight } \\
(\mathrm{g})\end{array}$ & $\begin{array}{l}\text { Harvest } \\
\text { index }\end{array}$ \\
\hline 88.0 & 25.4 & 119.6 & 222.2 & 0.538 \\
\hline 92.7 & 28.2 & 127.1 & 276.4 & 0.460 \\
\hline 88.5 & 27.6 & 129.7 & 221.6 & 0.585 \\
\hline 95.5 & 23.9 & 85.7 & 184.5 & 0.465 \\
\hline
\end{tabular}

$(\mathrm{A})^{*}$ and $(\mathrm{B})^{*}$ are the numbers measured at heading time and harvest time, respectively.

usual : the air temperature in August was $26.2^{\circ} \mathrm{C}, 1.4^{\circ} \mathrm{C}$ lower than the average $\left(27.6^{\circ} \mathrm{C}\right)$, and the sunshine duration was about $30 \%$ less than the average during the early half of rice growing season. In spite of such a climatic condition, the cultivars used here showed a vigorous growth as a whole, and it seemed to have little adverse effect on the growth and yield.

The yield and related factors are compared among the four cultivars in Table 1. The heading dates of Shanyou-6, Shanyou-63, Guangyou-6063 and Nipponbare were September 8, September 7, August 25 and August 29, respectively. Of these cultivars, Shanyou-63 was largest (276.4 g/plant) in dry matter weight, and the cultivars with the highest grain yield were Shanyou-63 (127.1 g/plant) and Guangyou-6063 (129.7 g/plant), both of which were about 1.5 times that of Nipponbare $(85.7 \mathrm{~g} / \mathrm{plant})$. Higher harvest indexes were obtained for Shanyou-6 and Guangyou-6063. High yield of these hybrids mainly depends both on the increased number of spikelets per panicle and plant and on the increased 1,000-grain weight. Having a large sink capacity may be a main cause of yield increase of the hybrids. On the other hand, the number of panicles per plant and the ripened grain ratio were a little less than those of Nipponbare.

\section{Distribution of dry matter weight in the aboveground parts of a plant}

Changes in dry matter weight of a plant, leaf + culm and panicle with growth are shown in Fig. 1. A large increase was shown in panicle weight of the hybrids compared to Nipponbare. Culm + leaf weight in Shanyou-6 and -63 showed a peak just after the heading and then decreased with maturing. The reduced weight $(* R)$ in culm + leaf may be considered to contribute to increase in panicle weight $(* \mathrm{P})$.

Maintenance of high photosynthetic rate after heading is a fundamental determinant to increase yield, and in addition, carbohydrate accumulation in culms and leaves before the beginning of grain-filling is also important as a yield determinant. A large * $\mathrm{R}$ shown in Shanyou-63 and -6 may suggest that these hybrids greatly depend for their yield on the imported substance, on the other hand, a higher post-heading 
photosynthesis seems more responsible for the increased yield in Guangyou-6063. Song et al. (1990) and Saitoh et al. (1991) noted that the amount of accumulated carbohydrate before heading was closely correlated with the yield of high yielding cultivars of rice. Such a phenomenon was also detected on other grain crops : for example, Kubota and Ueda (1981) reported that the larger accumulation of matter in the stover led to the high yield of corn plant.

The reduction in culm and leaf weight was larger in the late-heading cultivars (Shanyou-6 and -63). A similar trend was detected, though it was not so conspicuous, in Guangyou-6063 (early type) as well. The weight decrease in such organs during the maturing stage seems mainly dependent on translocation of the accumulated substance to panicles. In general, importance of the pre-accumulated substance in a plant is emphasized for late-heading cultivars, because the climatic condition (air temperature and solar radiation) becomes gradually less favorable for photosynthetic production during the grain filling time.

Table 2 summarizes the variation range in dry matter weight of each part of a plant during the reproductive stage. These values were calculated from the data written in Fig. 1. The contribution ratio of pre-accumulated substance to panicle growth is represented as a value of ${ }^{*} \mathrm{R} /{ }^{*} \mathrm{P}$.

Culm + leaf weight during the reproductive stage greatly increased $(* \mathrm{~W}=115.0$ to $137.5 \mathrm{~g} / \mathrm{plant}$ ) in the hybrids, and a larger increase was also shown in panicle weight $\left({ }^{*} \mathrm{P}=112.5\right.$ to $\left.136.0 \mathrm{~g} / \mathrm{plant}\right)$ of the hybrids. The difference between $* \mathrm{~W}$ and $* \mathrm{P}$ was almost negligible (1.5 to $2.5 \mathrm{~g} / \mathrm{plant}$ ) in both Shanyou-6 and -63 : most of the increased weight of a plant seems to contribute to the increase in panicle weight. Furthermore, in Guangyou-6063 the panicle weight increase exceeded the culm+leaf weight increase. This may be a reason of Guangyou-6063 having a higher harvest index as shown in Table 1. Contrary to this, the panicle weight increase $\left({ }^{*} \mathrm{P}=82.5 \mathrm{~g} / \mathrm{plant}\right)$ of Nipponbare was small and the value of ${ }^{*} \mathrm{~W}-* \mathrm{P}$ was large $(12.0 \mathrm{~g} / \mathrm{plant})$ compared to those of the hybrids. This may indicate that the sink capacity of grains of Nipponbare is restricted below the photosynthetic source capacity, and thereby the ratio of substance distribution to the other organs such as leaf and culm has increased.

* $\mathrm{R}$ of the hybrids was 31.0 to $57.0 \mathrm{~g} / \mathrm{plant}$, but that of Nipponbare was small (2.7 $\mathrm{g} / \mathrm{plant})$. The translocation of substance was not experimentally determined here, so that it can not be proved that $* \mathrm{R}$ is equivalent to the total amount of actually exported substances from culms and leaves. But panicles should be the largest sink for

Table 2. Dry matter weight increase in aboveground part $\left({ }^{*} \mathrm{~W}\right)$ and panicle $\left({ }^{*} \mathrm{P}\right)$, and dry matter weight decrease $(* \mathrm{R})$ in culm and leaf of the four cultivars during the reproductive stage.

\begin{tabular}{lcccrr}
\hline Cultivar & ${ }^{*} \mathrm{~W}$ & ${ }^{*} \mathrm{P}$ & ${ }^{*} \mathrm{~W}-{ }^{*} \mathrm{P}$ & $\begin{array}{c}{ }^{*} \mathrm{R} \\
\mathrm{g} / \mathrm{plant}\end{array}$ & $\begin{array}{c}{ }^{*} \mathrm{R} /{ }^{*} \mathrm{P} \\
\%\end{array}$ \\
\hline Shanyou-6 & 115.0 & 112.5 & 2.5 & 57.5 & 51.1 \\
Shanyou-63 & 137.5 & 136.0 & 1.5 & 51.0 & 37.5 \\
Guangyou-6063 & 120.0 & 131.0 & -11.0 & 31.0 & 23.7 \\
Nipponbare & 95.0 & 82.5 & 12.5 & 2.7 & 3.3 \\
\hline
\end{tabular}

Note; The values in the list were calculated from the data in Fig. 1. 

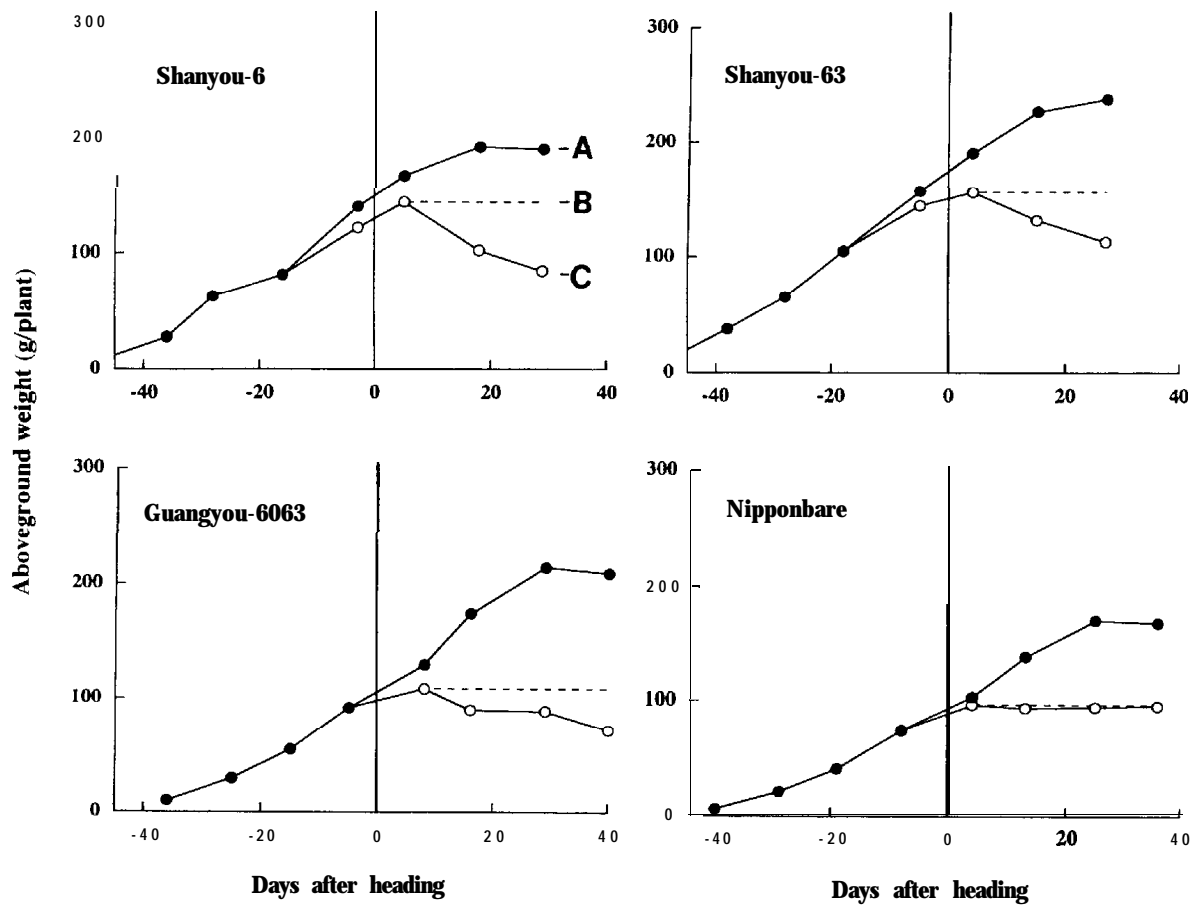

Fig. 1. Comparison of dry matter weight among the four cultivars Total aboveground weight $; 0$, culm + leaf weight including dead parts. ${ }^{*} \mathrm{~W}, * \mathrm{P}$ and $* \mathrm{R}$ are the total weight increase, panicle weight increase and culm+leaf weight decrease during the reproductive stage, respectively and calculated by $* \mathrm{~W}=\mathrm{A}-\mathrm{D},{ }^{*} \mathrm{P}=\mathrm{A}-\mathrm{C},{ }^{*} \mathrm{R}=\mathrm{B}-\mathrm{C}$.

photosynthate during the maturing stage, accordingly the ratio of ${ }^{*} \mathrm{R} /{ }^{*} \mathrm{P}$ may be regarded as an indicator for re-translocation capacity. The ratio increased in the hybrids : particularly that of Shanyou-6 exceeded 50\%. High yield of the hybrids is considered to largely depend on the pre-accumulated substance in culms and leaves. The rapid re-translocation to panicles seems very advantageous for increasing yield in the hybrids.

Variation in dry matter weight of leaf, culm and root with growth is compared among the four cultivars in Fig. 2. Leaf weight drew a mono-peaked curve, having a peak directly before heading for all the cultivars (Fig. 2A). Leaf weight of Shanyou -63 and -6 increased from the early stage of growth to 20 days after heading, but after this it reduced to the level below that of Nipponbare. Increased leaf weight of Shanyou-63 and -6 may be a cause of increasing the photosynthesis of a plant and substance accumulation in culms and leaves.

Culm weights of Shanyou-63 and -6 also show a large change with growth (Fig. 2B). The weights were 91.0 to $116.0 \mathrm{~g} / \mathrm{plant}$ at the maximum, which were about 1.6 to 2.0 times those (about $60 \mathrm{~g} / \mathrm{plant}$ ) of Guangyou-6063 and Nipponbare, and then decreased to the almost same level of Guangyou-6063 and Nipponbare. The culm is known as a main organ for carbohydrate accumulation, and the large reduction in culm 

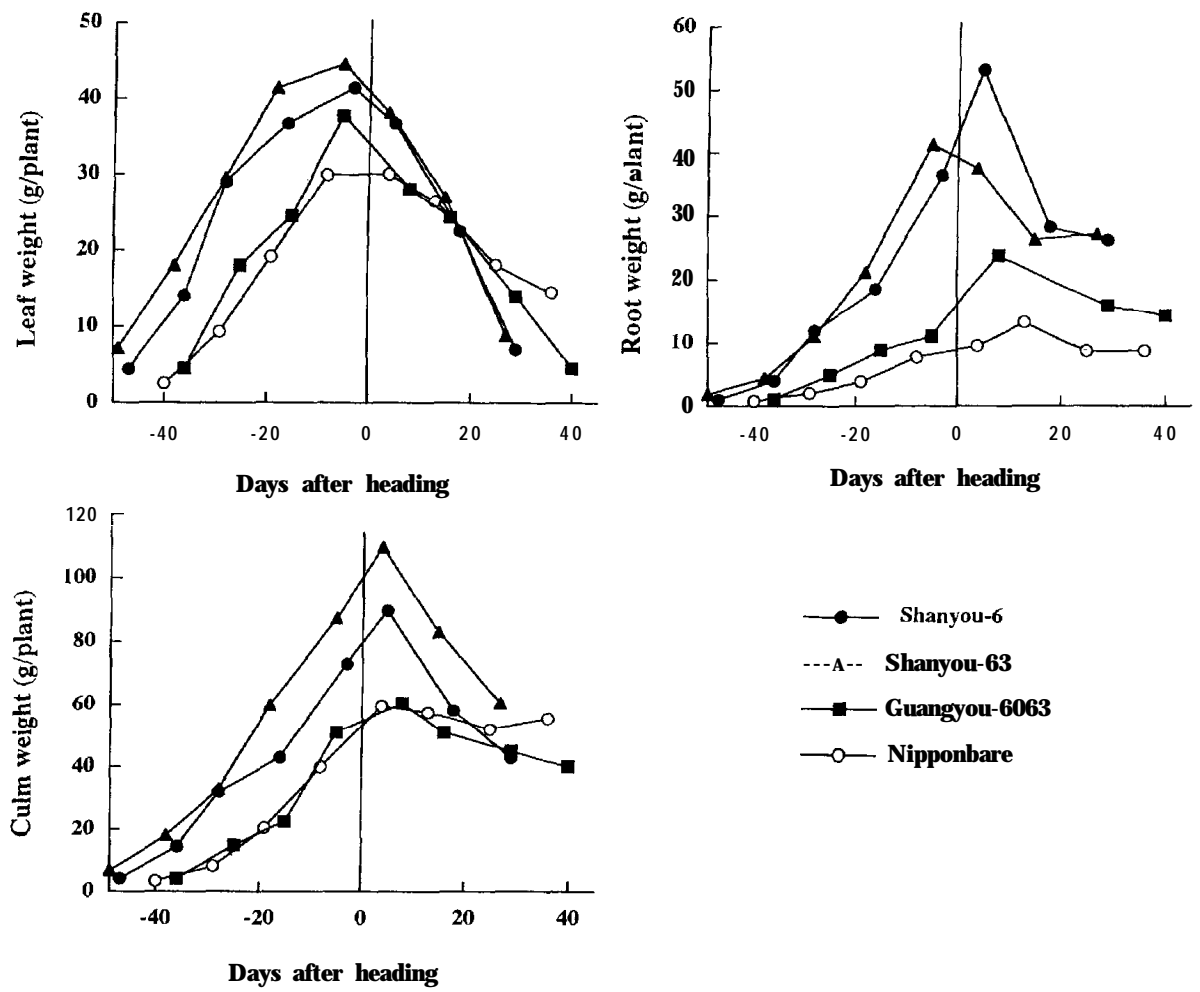

Fig. 2. Variation in dry matter weight of leaf, culm and root of the four cultivars with growth.

weight of Shanyou-63 and -6 suggests that their high yield, as mentioned above, depends on the translocation of accumulated substance from the culms.

The time course of root weight was similar in pattern to that of culm weight (Fig. 2C), but the inter-cultivaral difference in root weight was distinctive (Fig. 2C). Kubota et al. (1993) noted that hybrid rices were characterized by well developed root system, which may support a high potential of water and nutrient absorption, and Ichii and Nakamura (1990) detected the heterosis for nutrient uptake in hybrid rice seedlings.

Here we have been interested in the large reduction in root weight of the hybrids shown in Fig. 2C. Until now, the roots have not been regarded as a main organ of photosynthate pool in a rice plant. According to the report of Yoshida and Takahashi (1958), the content of carbohydrate and protein in culms and leaves was 25 to $30 \%$ of the total weight, but it was only 10 to $15 \%$ in roots. In general, the weight ratio of root to leaf +culm is small in a rice plant, and accordingly the total amount of accumulated substance in roots is so little that roots cannot be regarded as a source organ of substance export. However, the root weight of the hybrids was several times heavier than that of Nipponbare as shown in Fig. 2C. In the case like this, the substance accumulation in roots should reach a relatively high level and the roots seem 


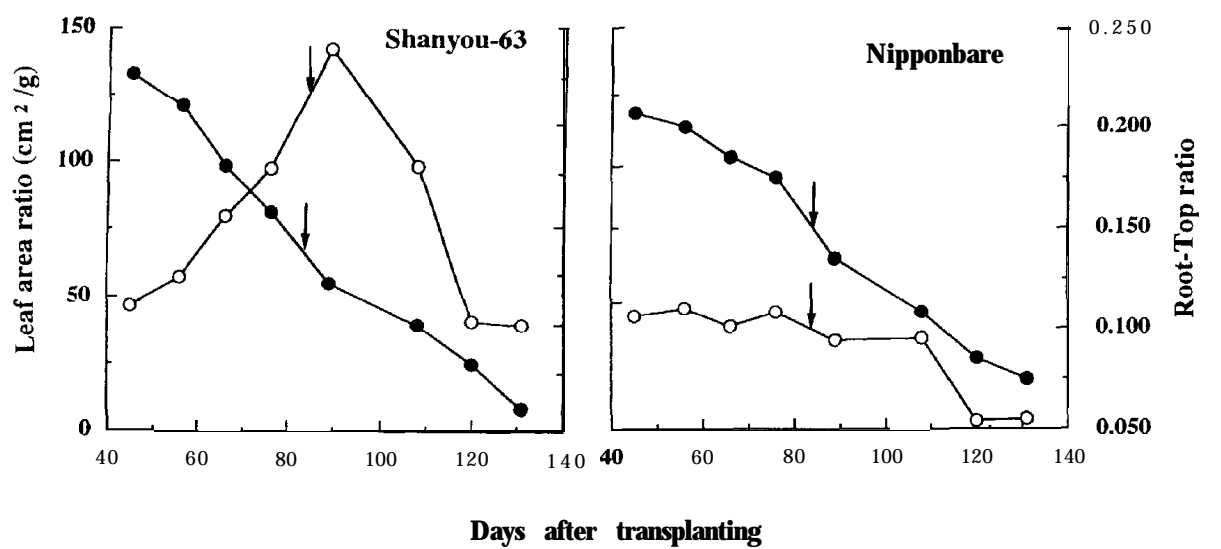

Fig. 3. Variation in leaf area ratio (O) and root-top ratio $(\bigcirc)$ of Shanyou-63 and Nipponbare. The arrows indicate heading time.

to play a significant role as a source organ.

Leaf area ratio (LAR) and root-top ratio are compared between Shanyou-63 and Nipponbare in Fig. 3. LAR showed an almost similar decreasing trend with growth in both cultivars. Contrary to this, there was a distinctive difference in root-top ratio between the cultivars : the ratio of Shanyou-63 drew a mono-peaked curve showing a large variation range with growth but that of Nipponbare was almost unchanged. This is evidence to prove that root of the hybrid is a source organ capable to export a considerable amount of accumulated substance to grains during the maturing stage.

\section{Variation in leaf photosynthesis with growth}

Leaf photosynthetic rates are compared among the cultivars in Fig. 4. During the early growth stage, higher rates were observed in the hybrids. A similar result was

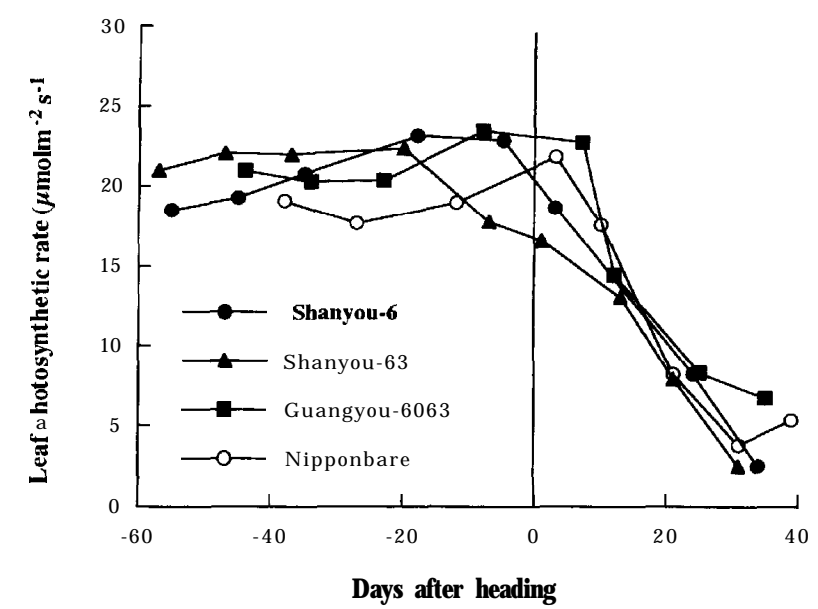

Fig. 4. Leaf photosynthetic rates of the four cultivars. 
noted by Song \& d. (1990) and Hirao \& d. (1995). The joined effect of high leaf photosynthesis and large leaf production may result in increasing plant photosynthesis and dry matter production of the hybrids. But after heading, both leaf photosynthesis and leaf amount of Shanyou-63 and -6 decreased more rapidly. One of the causes of photosynthetic reduction is the air temperature lowering during the maturing period of middle September to early October. Under this condition the grain fillings are more dependent on substance imported from the other organs.

The leaf photosynthesis in the hybrids was not so higher than expected. Leaf production is regarded as a more powerful contributor to the increase of dry matter production. Contrary to this, Hirao \&d.(1995) detected interest evidence that the hybrid rices showed a significantly higher photosynthetic rate than that of the pure line cultivars when the rate was compared on the basis of a unit weight of soluble protein or a unit activity of RuBPCarboxylase/Oxygenase. Further detailed understandings of heterosis effect on the enzymatic operation in photosynthesis are required.

\section{REFERENCES}

Hirao K., F. Kubota and W. Agata 1993 Dry matter production and photosynthesis in hybrid rice. In "Low-input sustainable crop production systems in Asia" ed. by KSCS (Korea), pp. 209-217

Hirao K., F. Kubota, W. Agata and X. F. Song 1995 Characteristics of leaf photosynthesis in Chinese $\mathrm{F}_{1}$ hybrid rice cultivar, Shanyou 63. Jpn.J. Crop Sci., 63 (in print)

Ichii M. and M. Nakamura 1990 Heterosis for nutrient uptake in $\mathrm{F}_{1}$ rice hybrid-seedlings. Jun. J. Crop Sci., 59: 140-145

Kubota F. and S. Ueda 1981 Environmental factors and productivity in silage corn (Zeamays L.). IV Effects of plant density, sowing time and fertilizing level on silage corn production. J. Japan Grassl. Sci., 27 : 190-199

Kubota F., Y. Watanabe and W. Agata 1993 Effects of roottcompetition on the photosynthesis and dry matter production of hybrid rice. 4 In "Low-input Sustainable Crop Production Systems in Asia" ed. by KSCS (Korea), pp. 429-440

Saitoh K., S. Kashiwagi, T. Kinoshita and K. Ishihara 1991 Characteristics of dry matter production process in high yielding rice varieties. IV Dry matter accumulation in the panicle. Jpn.J. Crop Sci., $60: 255-263$

Song X. F., W. Agata and Y. Kawamitu 1990 Studies on dry matter and grain production of $F_{1}$ hybrid rice in China. I. Characteristics of dry matter production. Jpn. J. Crop Sci., 59: 19-28

Song X. F., W. Agata and Y. Kawamitu 1990 Studies on dry matter and grain production of $F_{1}$ hybrid rice in China. II. Characteristics of grain production. Jpn. J. Crop Sci., $59: 29-33$

Yoshida T. and J. Takahashi 1958 Studies on the physiological activity. 2. Change in the content of functional organic matters in a rice plant with growth stage. Jpn. J. Soil Sci. Plant Nutr., 29: $251-254$ 